にされた究極の段階で，はじぬて明確にされるものでは あるが，振動に関する研究をさらに屡開する上に抏いて， 音響心理学の実験で音の大ささの評亚がなされ，艺れが その分野の研究を大きく展開させたことを想起したい。 即台 Flecher-Munson の等ラウドネス曲線とLoudness Level あるいは等比法によって Sone といら笚位で評洒 したと同じ方法で．振動感覚の大きさを評洒することで ある。Vibration と Noise はたがいに随伴するので， 両者の複合された感覚の評価にまで止揚することを目的 としているが，その前段階として，演者は松平式振動試 験機を使用して，人体の耐容度，試駼機の精度から，振

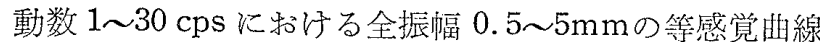
の作製を試みた。被験者は 20〜35 歲の健康男子40名， 振動は指先，眼あるい柱身等で知覚されるが，今回は 立位で全身的に振動を負荷した場合について観察した。 振動方向による相異も遍究するために, 重焉, 前後, 左 在の 3 方向成分の振動について行なった。また振幅, 振 動数の弁別に関する実験をも行ない, さらに method of multiple stimuli によって, sone scale $の$ 加き ratio scale によって，振動の大きさを钼察したので，その成 續を報告する。

\section{3. ストレインゲージの振動計測への忍用}

\section{三䑳俊輔（学衛研）}

近時，振動工具による振動疾病の間題がかなり取り上 げられ，衛生学的研究は相当に焦められつつあるが，振 動工具の振動の伤析及びその防振の閣題はあ本り研究さ 机ていないのが現状である。そこで，この問題を検討し ようとして，まず，振動の忠実再生用ピック・アップの 試作を行なったので報货する。

憲々の直面する振動工具の振動を計測するには, つぎ の要件を满足せ小ばならぬ。

(i) 衝撃性の振動をできるだけ思突に再生できるこ と(ii)大加速度で非線型にならぬこと（iii）小加速度も 测定できること（iv)小型軽量堅审であること（v)で

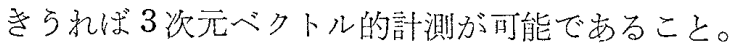

以上の条件を充たす振動ピック・アップとして，璐波 数特性の平坦性及び感度の点よりして，1稞頪で全要求 を渾足することは不可能である。

この目的にかならものとしては，現在はチタバリの振 動ピック・アップが種々研究南貶されているが，目的に応 じて自作することは困難である。しかるにストレィン・ゲ

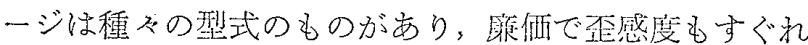
ているので，自分で畺当な振動系を試作して，これには
りつければ，容易に振動ピック・アップとなる。また較 正しながら使用するのであれば，ストレィン・ゲージの 回路は簡単にする，さらに著るしい特色は工具自体へス トレィン・ゲージを接着することも可能である。かかる 利点を考慮し，゙゙ージの振動計测への利用を考えた。

振動系は粼青銅板バネ材を用い，その維振動または横 振動を利用した。各要素は 3 次元的に組合わせ，各出力 の位相を求めてべクトル空間の象限をきめた。本振動ピ ック・アップの較正は MB社の C31 型振動台によって 行なった。詳細なデータは口述する。今後はこれを実際 の衝撃性の工具の測定解析に旗用してみようと思う。

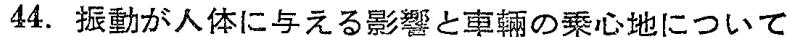

山本翰夫，山本武㴔，寺尾浩明（順天堂大公衛）

ある程度の振動は，生体に初期ショック症状に類似の 影響を与完，生体協関を変光ることは従来より行なわれ ているショックあるいはストレスの研究の報ずるところ である。私详は，最近，市暊されている振動椅子が生体に 与光る作用機序が基礎的研究の行なわれることなく用い られている笑情を検討していたが，これらは振動が生体 にショック症状を与え，これが渡学感の減退に影響を与 えていること学認めた。そこでさらに正しい加速度，振 動数と生体反応との関係を知りたいと思い，国鉄中央技 術研密所の協力を得て，松平式振動台を用い，振動之慒 心地之の関係索国鉄基準の加速度 $0.03 \mathrm{ga}$ を中心， $0.01 \mathrm{ga} \sim 6 \mathrm{ga}$ ，振動数を $15 \mathrm{c} / \mathrm{sec} \sim 30 \mathrm{c} / \mathrm{sec}$ 汇置いて， 赤, 白球数，好酸球数，血压，脈搏，皮膚温度，血中 $17 \mathrm{ks}$ 等について比較検討した。その結䑁，生体が注と えぞ振動を感知し得ないような場合でも，好酸球数が著 明に反応し，以下，皮膚温，脈搏数， $17 \mathrm{KS}$ 等飞影響が 認められており，振動が初期ショック症状の形で生体に 影響を与えていることがわかるが，これらの知見に補な って，振動の疲学に及ぼす影響，その利用範国等につい て触れてみたい。

\section{〔異常 気 王〕}

\section{5. 加压の人㮏に及ぼす影響（第 2 犃） 䏚器の病理学的变化について}

\section{斎藤春雄, 蛒谷 清 (学衝福沚衛生会)}

私ども虻，昭和35年 6 月の本学会総会に数いて，加正 の人体に及ぼす影響について，+0.7 気玨前後の加区 を，氮正タンクを用いて，人体に加光ると，各種神経性 